Europe's Journal of Psychology, 7(3), pp. 502-533

www.ejop.org

\title{
Psychotherapy of ultra-orthodox Jews in Israel - A qualitative assessment of conflicts and reconciliations
}

\author{
Esther Hess and Horia Pitariu \\ Department of Psychology, UBB University, Cluj
}

\begin{abstract}
The ultra-orthodox Jewish community in Israel is highly homogeneous and is virtually isolated from the surrounding secular society. Nevertheless, in recent years some openness to psychotherapy has emerged. In this paper the first author, herself a member of the ultra-orthodox community and a psychotherapist, presents a series of analyses and discussions of the major issues raised by therapy amongst members of this community. This study had two main objectives: a) a qualitative assessment of possible conflicts between the subjects strong religious convictions and the essence of psychotherapy; some conflicts were indeed detected which were followed by individual modes of reconciliation, b) an attempt to discover whether the psychotherapy had an impact on the level of observance of the Jewish commandments and customs; some indications for a lessening of such observance were found. This study, being the first of its kind, could provide a basis for studying the effects of psychotherapy on subjects belonging to isolated communities.
\end{abstract}

Key words: psychotherapy, orthodox Jews, religious convictions, homogeneous societies

The ultra-orthodox Jewish community in Israel is probably familiar to only a few readers. Ultra-orthodox Jews have an unwavering belief in God. They believe that everything is ordained from above, that everything that happens is for the good, eventually; they believe in reward and punishment, in the power of prayer, in observing the commandments and in clear lines of personal philosophy. Continuing and extensive study of the Torah (the oral and the written law) is a supreme value and is regarded as the primary source of knowledge. Life in this community is based on observance of the Jewish religious commandments and customs. Children are strictly educated in accordance with the Jewish traditions, and separation between 
the sexes is rigidly enforced in all educational and community frameworks. The community has its own separate institutions and is largely isolated from the outside world. The only source of news and information is the ultra-orthodox press: television, movies and theater are not permitted. The Internet is used only for business and is forbidden to children. It should be noted that the ultra-orthodox communities in Israel are far more closed than their counterparts in Europe or the USA. The writer of this article is herself a member of this community and consequently faces a serious dilemma: on the one hand, she is expected to adhere to their absolute, unbending rules and norms of behavior and on the other hand, her professional status as a psychotherapist allows her a certain amount of distance and neutrality in her observations. This combination creates a unique personal and professional perspective for her research on her patients' experiences in psychotherapy. For members of this community, the exposure to psychotherapy is a breakthrough into the open world that enables and even encourages cognitive pluralism. This encounter creates major difficulties during the therapy.

\section{Literature review}

The encounter between psychoanalysis and religion has been studied from several different viewpoints. Irvine (2003) and Walker, Gorsuch, \& Tan, (2004) have examined research conducted by psychotherapists on the use of their religious experience. Coltart (1992, p. 244) writes of psychoanalytical therapy amongst religious Christians, raising the power of conscience that, she avers, underlies every religion, and the difficulty in conducting psychoanalysis with religious Catholics:

"Roman Catholics who have been brought up from the cradle in the faith ascribe this, to an extent quite properly, to the thoroughness of early indoctrination; it is a well-recognized fact among analysts that to analyse even a long lapsed Catholic presents one with a certain harsh and unrelenting set of problems connected with the tyranny of the conscience. But the oddity of this self-observable fact - that the conscience may have twists and powers that seem inexplicable in terms of conscious awareness and recall of early life - also occurs frequently in people from non-religious backgrounds".

Spero (1981), Case (1997), and Sieve (1999) have written about countertransference with religious subjects; Marx and Spray (1972), Weisbord (1982,) Houts \& Graham (1986), and Giglio (1993) have written about the effect of differences in religious perceptions between therapists and subjects; and Erlanger (1988), Cohen (1994), Greenberg (2001), Irvine (2003) and Novis Deutch (2010) have written about 
the way in which religious therapists handle the conflict of values between the religious and the professional worlds. Writers such as Spero, $(1980,1996)$ and Arnovich (2003) have dealt with conceptual and philosophical aspects that entail compatibility in principle, or with essential contradictions (Amsel, 1969; Rotenberg, 1990-2005; Rosenheim, 2003, 2004, 2008; Novis Deutsch, 2010). Hoffman (2007) also related to issues that concern the observant therapist and his or her personal coping in this complex encounter. Additional studies have been conducted in other domains such as philosophy (Buber, 1962, 1976; Levinas, 1982, 2007) and education (Rosenak, 2003, 2005).

Those who have written on the encounters between psychoanalysis and Judaism fall into three main groups:

1. Psychoanalysts working with religious Jews. These researchers attempt to gain a deeper understanding of the ultra-orthodox mentality in order to create a better connection with their patients and to open up the possibility of therapy (Bilu and Witztum, 1994; Witztum and Greenberg, 2002).

2. Religious clinicians who work with the ultra-orthodox population and encounter the continuing tensions between the ultra-orthodox lifestyle and the more open and permissive thinking of psychotherapy. These tensions manifest themselves in several areas: the need to observe the multiple laws and requirements of orthodox Judaism in everyday life, the question of what is permitted and what is forbidden according to Jewish law, closedness compared to openness, the requirement to study Torah as opposed to the study of general subjects, acquiring a profession and sex-related topics such as pre-marital sex, homosexuality and masturbation, all of which are prohibited by Jewish law.

3. Rabbis who guide the orthodox Jewish public and who handle questions asked by the therapist or the subject on topics where a conflict arises between issues raised in the therapy and Jewish law. The best-known of these was the late Rabbi Moshe Feinstein in the United States, whose authority as an adjudicator on matters pertaining to Jewish law was recognized throughout the Jewish world. His responses to questions regarding psychotherapy (among other issues) were published in his eight-volume work known in Hebrew as "Iggerot Moshe" (freely translated, "Letters from Moshe", 1973).

In recent years, several therapeutic trends have been developed with the goal of creating a conceptual - philosophic integration between psychodynamic understanding and Judaism (Rotenberg, 1997, 2001, 2004; Caspi, 2002; Ginzburg, 
2004 a, b). In addition, Adahan (1997, 2002, 2005) and Twersky (1997, 1999) have developed a cognitive-therapeutic approach to issues in Judaism. Till now, however, no research has been conducted that focuses on the place of the patient in the encounter between these two Weltanschauungs - Judaism and psychotherapy. The research presented in this paper is original and unique in that it is conducted from a dual perspective: from within, from a personal starting point, from a place of belonging, and from without, from a psychological-anthropological viewpoint and through the professional therapeutic work.

\section{Qualitative research}

As Einstein said, not everything that is important can be calculated. And thus, the realm of psychotherapy that deals with the delicate matters of the soul demands special and sensitive measurement. Since psychotherapy is derived from the world of medicine, one would expect to find a wide range of studies in this field. However, very few studies have been carried out on the therapeutic process - a fact which in itself is worthy of further investigation. Sheffler $(1989,1994)$ writes that empirical research is problematic when pertaining to the soul. The credo in psychotherapy is that the individual is unique. Creswell (1998) has defined qualitative research as follows: "Qualitative research is an inquiry process of understanding based on distinct methodological traditions of inquiry that explore a social or human problem. The research builds a complex, holistic picture, analyzes words, reports detailed views of informants, and conducts the study in a natural setting" (p. 15). Qualitative research talks "with" people and not "about" them. The researcher is connected to and involved with the experiences of his or her subjects. The uniqueness of qualitative research lies in the relationship between the researcher in the social sciences, and the objects of his/her research. In this type of research, the relationship is not one of subject and object, but rather a subject-subject relationship (Sciarra, 1999).

Sabar ben Yehoshua (2002) believes that qualitative research offers the best means of understanding human activities and providing interpretations for social phenomena and emotional processes, since it allows the researcher to observe what occurs in the "black box" of the human mind. She believes that the researcher's task is to examine the ideas from a standpoint of perceptive interpretation, "from the outside in", and also to view the topic "from the inside out", based on the researcher's own deep understanding of the method.

It is true that the observation is also subjective, but this is the nature and uniqueness of qualitative research, of which Buber (1962, pp. 10-11) said: "Everything the philosopher finds in a person of the first generations or a modern person, in males 
and in females, in Indians and in the Chinese, in fools and in geniuses, he will develop around what he discovers within himself through observing himself, and only then will he understand philosophical anthropology" (freely translated from Hebrew).

\section{Research methods}

The research methods employed in this paper may be described as phenomenological, ethnographic and narrative. As noted, the research was conducted from a position of close familiarity with the population studied. When a study deals with the culture to which the researcher himself belongs, there is a deliberate attempt to see everyday events in a new light. The researcher strives 'to make the familiar foreign' or to use the familiar in order to understand, while simultaneously distancing himself or herself from his/her normal level of understanding and familiarity.

In phenomenological research, concepts and categories are drawn from the subjects' own idiosyncratic interpretations of reality. These concepts and categories are then studied on the basis of the subjects' own narratives, as documented by the researcher (Selman, 1980).

The phenomenological analysis in this paper is based on Bion's concepts in the areas of object relations and early development. Bion used the phenomenology of the analytic hour as his starting point, highlighting the two principles of the emergence of truth and mental growth. The mind grows through exposure to truth. For Bion, the emotional experience is the foundation for both mental development and truth. He provides a language and the tools to help the therapist reflect, outside the analytic hour, on what has occurred during the treatment. Bion's work also has a spiritual element which brings him closer to a religious viewpoint (see Bion, 1959, 1962, 1963, 1965, 1967, 1992).

Ethnographic research deals with the description and study of a culture, based on observation of a social group with a shared culture. The culture includes the concrete symbols that people use to express themselves, as well as the meaning afforded the symbols. Each cultural group has its own intra-cultural codes and language. Ethnographic research is conducted, as noted, within the community studied, with the dimension of inward observation and the interpretations of the research subjects. This is followed by the outside interpretation (Shkedi, 2003). 
Geerz (1990) defines ethnographic research as complex observed behaviors that have both concrete and symbolic significance. Members of the community carry a very intricate and detailed internal "map" of the socio-economic and other parameters used to assess behavior within their group, but they are often totally unaware of these criteria or else they are only aware in a very vague and ambiguous manner. Accordingly, one of the main goals of ethnography is to bring out topics which are hidden or self-explanatory to the subjects, and to make these topics overt and explicit.

Narrative research

The data used in this study were taken from summaries of the psychotherapeutic sessions written by the researcher in her personal logbooks. These logbooks were aimed to provide a close record of the work done in each session and were not originally intended as a basis for research. In such situations the research is carried out on a current phenomenon in a real environment (Walker, 1993, and Yin, 1994), and the researcher has little control over the events. The content is unstructured and not based on previously constructed questionnaires or interviews (Carter, 1993, in Shkedi, 2002, pp. 47-48).

The material also reflects the author's dual viewpoint: his or her personal position as a member of the religious ultra-orthodox community, and his/her professional position as an "external" participatory therapist and witness.

\section{The research objective}

The general aim here was to study the encounter between psychoanalytically oriented psychotherapy and ultra-orthodox observant Jews, based on the clinical work and focusing on the subjects' experiences within the process. The research questions were in this case:

1. Do the similarities and the differences between psychoanalysis and Judaism create conflicts for which compromise and mediation can be found?

2. How does each patient's individual inner world affect his or her ability to cope with religion-related conflicts during the therapeutic process?

3. Does psychodynamic psychotherapy for a religiously observant person undermine their faith and lead to a reduced commitment to observing an orthodox way of life? Or does it simply hasten processes that would have occurred in any case? 


\section{The research subjects}

The research sample was selected from the logbooks written by the first author over a period of ten years. Special attention was paid to the following criteria: All the subjects were from a homogeneous population representing the research population. All were ultra-orthodox Jews who regard themselves as members of that community and accept its philosophical, religious and belief values. All were adults and adolescents who could express themselves verbally.

The participants

1. Chavazelet. A married female aged 32, mother of five children and working in the field of education. She was the youngest child in a family of many children whose parents were overburdened and unable to offer her any guidance in coping with everyday problems. She married at the age of 17 and had a series of miscarriages when she was not yet mentally or physically ready for them, as she was still a child herself. Chavazelet sought therapy with this author about a year after her fourth pregnancy, when she was depressed and her self-image was low. She had a tendency towards isolation and self-restraint.

2. Yael. An unmarried female aged 28 , studying and working in education while living at home with her parents in an extremely orthodox family. Yael is the oldest child in the family. Her parents are very extreme and meticulous in their observance of the religious commandments, demanding the maximum of their children. Yael strived towards perfectionism, trying constantly to satisfy her parents and her teachers. In the framework of her higher studies she suffered a crisis manifested as withdrawal and avoidance, with a heightened depressive mood. She sought therapy with this author after three attempts at cognitive behavioral therapy.

3. Assaf. An 18-year-old student at a Yeshiva (college for religious studies), who lived at home with his parents. He grew up as a second child in a family where the parents found it hard to set limits and he therefore had difficulties with accepting authority. Unable to function in a regular study framework, he had outbursts of anger when he encountered refusal or opposition. He approached the author at his own volition, on the recommendation of his last place of study from which he was expelled. In this case the Yeshiva (orthodox school) recommended the author, as she was ultra-orthodox herself and thus considered trustworthy. 
4. Keren. Unmarried female, aged 20, living at home with her parents. Worked as a secretary and studied in a higher education framework. Keren was the youngest of three children, an introverted, rather demanding and never-satisfied young woman with few friends. She came for therapy at her parents' initiative and on the recommendation of her school psychologist, who suggested a dynamically oriented therapy.

Table 1: The hours and sessions comprising the study

\begin{tabular}{lllll}
\hline Subject's name & $\begin{array}{l}\text { No. of } \\
\text { sessions } \\
\text { per week }\end{array}$ & $\begin{array}{l}\text { No. of years } \\
\text { of therapy }\end{array}$ & $\begin{array}{l}\text { No. of hours } \\
\text { of therapy }\end{array}$ & $\begin{array}{l}\text { No. of hours of therapy } \\
\text { analysed in the current } \\
\text { research }\end{array}$ \\
\hline 1 Chavazelet & 2 & 5 & 400 & 100 \\
2. Yael & 2 & 3.5 & 280 & 80 \\
3. Assaf & 1 & 1.4 & 45 & 45 \\
4. Keren & 1 & 8 & 400 & 100 \\
\hline
\end{tabular}

\section{The Research Process}

The research process consisted of three stages.

In the first stage, the material from the logbooks was arranged into chronological units. The preliminary classification was conducted according to the chronological development of each participant (Huberman \& Miles, 1994). It should be noted, however, that this classification follows the personal development of each subject during the psychotherapeutic process rather than a particular time frame.

In the second stage, the texts and the narratives were classified according to key topics. These topics, in turn, were organized into five "super-categories":

1. Therapy and Halacha (Jewish religious law, customs and traditions). This "supercategory" includes the largest number of narratives and many of the key issues that arose during the therapy.

2. Religion and knowledge, including self-knowledge

3. Drives and impulses

4. The therapist as an authority

5. Guilt as an emotion

In the third stage, the material was analysed along two primary axes - a longitudinal and a latitudinal axis. 
1. The longitudinal axis: The analysis of the material on this axis relates to the personal development of each subject during the different stages of therapy (beginning, middle and advanced - see below). The focus here is on the development of personality during the therapy and the influence of this development on issues related to belief and Halacha. This analysis was conducted within the framework of Category 1 - the category of Therapy and Halacha, and was based on analytical psychodynamic observation, object relations theory and the work of Bion (1959, $1962,1963,1965,1967,1992)$.

The classification follows the patient's chronological and personal development through three main stages of therapy:

a. The beginning stage - at this time, belief and doubt exist simultaneously but are still being explored. The patient expresses fear of change, and fears and questions about the therapy process.

b. The middle stage - during this stage, the patient is familiar with and trusts the therapist. The logbooks for this period show freer expression and a sharper description of the conflicts.

c. The advanced stage - at this stage the therapy progresses to a stage of insight and an attempt to integrate these insights with life experiences. This stage continues until the termination of therapy.

This section of the research is based on top-down observation, moving from conceptualization and theory to field data (Shkedi, 2003).

2. The latitudinal axis: The analysis of the material on this axis explores the topics covered under Categories 2-5 (above). Each of these categories contains various sub-categories from the narratives.

The in-depth topic analysis was carried out by comparing several research subjects simultaneously, while each one was at the identical chronological-developmental stage of his/her therapy (see stages $a, b$ and $c$ above). This section of the research is based on bottom-up observation, moving from field data towards conceptualization and theory (Shkedi, 2003). 


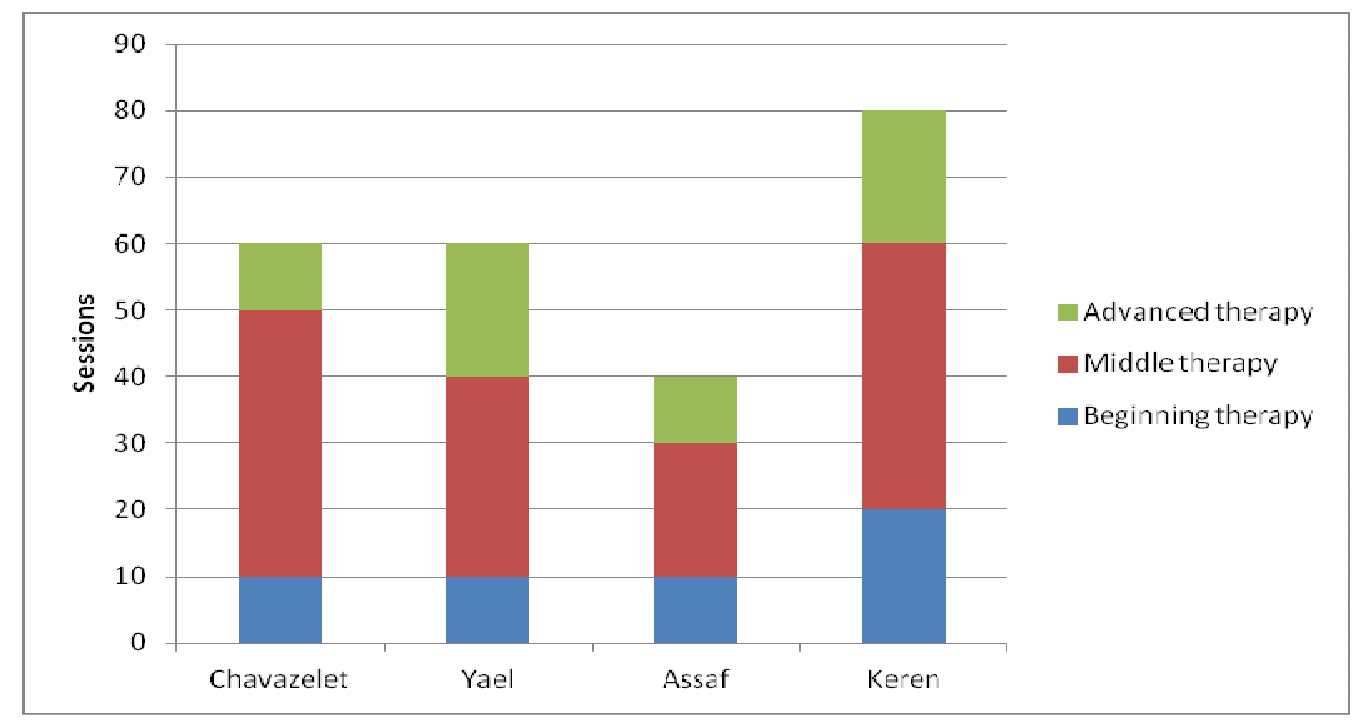

Figure 1: The number of therapeutic sessions relative to each stage of the therapy

\section{Results}

The research findings were organized according to the categories listed above (see also a summary in Table 2).

Category 1: Therapy and Halacha. Questions which arose around the therapeutic experience enabled space for wider thought in this category, while simultaneously coming into conflict with the demands of an ultra-orthodox way of life. This topic recurred in almost every session, because there is no area of life which remains unaffected by the religious laws and requirements. One example of this type of conflict is the question of whether to go for therapy at all. Does this not contradict belief in God, who is omnipotent? Does going for therapy mean that one's own religious belief is not strong enough? Is one allowed to talk about "forbidden topics" such as attraction towards another person?

Category 2: Religion versus knowledge, including self-knowledge. This category included the patients' own narratives: Is one allowed to know, is there value in knowing, or does knowledge contradict belief. An example of the effect of exposure to knowledge is shown in the response of one of the subjects during a discussion on the forthcoming elections in Israel. When she was asked "Who will you vote for?" her spontaneous answer was "Whoever the rabbi tells us to vote for". She was shocked by her listeners' reactions. She suddenly learned that one can make one's own choices, and decide for oneself for whom to vote. There are now two voices in the dialogue - the voice of the new knowledge and the voice of the Halacha. This creates a painful situation for the subject. 
Category 3: Drives and impulses. Examples of drives and impulses include anger and aggression, self-fulfilment, nurturing and emphasizing femininity and the sexual drive. The freedom of thought and speech afforded by therapy conflicts with the restrictions and prohibitions laid down by religious law. Subjects showed varying levels of openness in this category, but in all cases there was a great deal of anxiety regarding speaking about, or even thinking about, "forbidden topics".

Table 2: Analytical categories

\begin{tabular}{|c|c|c|c|c|c|}
\hline & $\begin{array}{l}\text { Category 1: } \\
\text { Therapy and } \\
\text { halacha } \\
\text { (Jewish } \\
\text { religious law, } \\
\text { customs and } \\
\text { traditions) }\end{array}$ & $\begin{array}{l}\text { Category 2: } \\
\text { Religion or } \\
\text { knowledge }\end{array}$ & $\begin{array}{l}\text { Category 3: } \\
\text { Drives }\end{array}$ & $\begin{array}{l}\text { Category 4: } \\
\text { The therapist } \\
\text { as authority }\end{array}$ & $\begin{array}{l}\text { Category 5: } \\
\text { Guilt as an } \\
\text { emotion }\end{array}$ \\
\hline Significance & $\begin{array}{l}\text { Rules and } \\
\text { halacha vs. } \\
\text { pluralism }\end{array}$ & $\begin{array}{l}\text { Knowing and } \\
\text { opening up } \\
\text { contradict the } \\
\text { unchanging } \\
\text { laws of } \\
\text { Judaism }\end{array}$ & $\begin{array}{l}\text { Drives and } \\
\text { impulses that } \\
\text { must be } \\
\text { restrained } \\
\text { according to } \\
\text { Judaism }\end{array}$ & $\begin{array}{l}\text { The therapist } \\
\text { vs. authority } \\
\text { figures such } \\
\text { as rabbis } \\
\text { and } \\
\text { teachers }\end{array}$ & $\begin{array}{l}\text { Emotion } \\
\text { accompanying } \\
\text { all thoughts or } \\
\text { actions that are } \\
\text { not compatible } \\
\text { with the } \\
\text { demands of } \\
\text { Judaism }\end{array}$ \\
\hline $\begin{array}{l}\text { Examples } \\
\text { from the } \\
\text { narrative }\end{array}$ & $\begin{array}{l}\text { "Is one } \\
\text { allowed to } \\
\text { be angry at } \\
\text { one's } \\
\text { parents while } \\
\text { in therapy?" }\end{array}$ & $\begin{array}{l}\text { Knowledge } \\
\text { that observing } \\
\text { the command- } \\
\text { ments } \\
\text { demands } \\
\text { forgoing } \\
\text { certain } \\
\text { experiences } \\
\text { and pleasures } \\
\text { in life }\end{array}$ & $\begin{array}{l}\text { Therapy } \\
\text { encourages } \\
\text { free } \\
\text { expression; } \\
\text { Judaism } \\
\text { demands } \\
\text { restraints to } \\
\text { all creative } \\
\text { expression }\end{array}$ & $\begin{array}{l}\text { "How can I } \\
\text { trust the } \\
\text { therapist } \\
\text { who studied } \\
\text { outside the } \\
\text { orthodox } \\
\text { religious } \\
\text { framework? } \\
\text { He/she is not } \\
\text { God" }\end{array}$ & $\begin{array}{l}\text { "I said things } \\
\text { that were } \\
\text { forbidden, had } \\
\text { forbidden } \\
\text { thoughts, certain } \\
\text { drives and } \\
\text { impulses arose in } \\
\text { me" }\end{array}$ \\
\hline
\end{tabular}

Category 4: The therapist as an authority: In the transference process, the therapist is positioned between divine authority and human authority. The attitude towards the therapist ranges from fear to admiration and to contempt. In the orthodox Jewish community, the attitude to authority - of God, of the rabbis, of educators and of one's parents - is one of acceptance and unquestioning obedience. This attitude is inculcated from an early age and is not open to discussion. Since the therapist is not a rabbinic figure or spiritual guide, the patient may wonder to what extent he can 
trust him or her. In many cases, the therapist's authority is regarded with appreciation and respect, but at the same time there are deep reservations about the professional aspects of his/her work that does not always comply with religious law.

Category 5: Guilt as an emotion. Guilt about being in therapy, about changing one's view of life and about changing one's attitude to the observance of religious law developed as a result of the therapeutic experience. Going to therapy can be interpreted as a lack of sufficient faith and religious belief and ensuing feelings of guilt. It is as if the patient is saying "If my faith were stronger, I wouldn't need therapy, so I feel guilty of lack of faith". An additional element is guilt about the cost of therapy; the patient may feel that this money should be spent on his family or on charity rather than "wasted" on therapy.

\section{Longitudinal analysis}

As mentioned earlier, the longitudinal analysis covers Category 1 - Therapy and Halacha. This category clearly presents the sharp conflict between religious law and human desires. The subjects' methods of coping vary with their personalities; their ability to cope depends on the intensity of the super-ego and the parental, educational or other internalizations it embraces. The material indicated diversity in the ability to cope with the conflicts between the closed and the open worlds, between personal desires and fantasies on the one hand and the restrictions of religious law on the other. In this category, coping mechanisms are dependent on three main variables a) the subject's age; b) personal background, the inner world that of internalization; and c) the length of therapy.

a) Age: The older subjects manifested a more developed, demanding and binding super-ego. The world of value internalization may be richer due to age, as well as to the accumulation of personal and community life experiences that afford a picture of a "syntonic super ego". These subjects contrast with the two younger subjects, for whom the boundaries were not rigid, or for whom ignoring or bypassing the boundaries was an easier way of coping than direct confrontation. The fear of being found out was still discernable; the patient's conscience is awakened, and at the same time the therapist is an accomplice to secrecy of the "crime".

b) Personal background: Subtle differences in the inner world and the world of internalization were evident, as well as in the subjects' education and upbringing. Statements indicating the intensity of the subjects' super-ego were voiced. The subjects responded to the external parental voices, viz-a-viz the religious laws, religious decisions and community norms as well as the internalized parental voice. 
The super ego was rigid; the "syntonic super ego" echoed clearly in discourse; the ego lacked dissonance; the ability to think and observe did not exist and was not even conceivable.

c) Length of therapy (between the third and the fifth year): The lengthier treatments revealed more daring, open narratives and a greater ability for free expression despite the religious laws. Narratives indicated greater freedom of thought and flexibility, as well as attempts to organize the relationship between the therapy and religious law (compared to the first stages of therapy). This was not yet real integration but the ability to differentiate and to see several aspects simultaneously. Two examples can illustrate this type of differentiation: the use of language that was permitted in therapy but would not be acceptable in the patient's external world, and the "permission" to have fantasies or even to fulfill (some of) these fantasies, with meticulous assurances from the therapist that absolute discretion would be maintained. There was a concrete learning of the existence of conflict; dissonance in the ego was generated, and consequently there was a manifestation of the suffering created by this conflict.

Three methods of coping with the conflict were observed: fixation / remaining in the conflict, compromise and mediation.

1. Fixation / remaining in the conflict was found at the start of the therapy, when the subjects protected themselves from change. It also indicated that the therapeutic process would be more complicated.

2. Compromise was possible at an advanced stage of the therapy, after some softening of the super ego had taken place (Freud, 1923). This was a nonintegrative type of coping. It was the simultaneous holding of two perceptions - understanding and attention to the needs of the patient's inner world, while maintaining the other side, the religious law or the authority figures who represented it. This process may be considered in a positive light as the development of some flexibility, but it could also be regarded as giving up on the dimension of depth by "flattening" the conflict.

3. Mediation means creating a kind of "bypass", in situations where the patient sees no possibility of combining and integrating the gaps between Orthodox Judaism and the needs of the self. The therapeutic process creates an unbearable dissonance in the ego, and in self-defence the patient turns to a type of coping characterized by ignoring or bypassing the prohibitions while at the same time taking care of his or her own inner needs. 
Another possibility is that the super ego had never developed and had no significant presence. It is also possible for the super ego to become an ally of the ego, by finding moral justification for fulfilling one's personal needs (Ericson, 1968).

\section{Latitudinal analysis}

\section{Category 2: Religion or knowledge}

Sub-categories mapped from super-category 2 - religion or knowledge - are presented below in Table 3.

\section{Table 3: Categories for religion or knowledge}

\begin{tabular}{lll}
\hline $\begin{array}{l}\text { Beginning stage of } \\
\text { therapy }\end{array}$ & Middle stage of therapy & $\begin{array}{l}\text { Advanced stage of } \\
\text { therapy }\end{array}$ \\
\hline $\begin{array}{l}\text { Knowledge exposes an } \\
\text { unbearable truth }\end{array}$ & $\begin{array}{l}\text { Knowledge as exposing } \\
\text { truth that arouses guilt }\end{array}$ & $\begin{array}{l}\text { Knowledge becomes } \\
\text { a significant factor }\end{array}$ \\
$\begin{array}{l}\text { Knowledge causes patient } \\
\text { to violate prohibitions }\end{array}$ & $\begin{array}{l}\text { Knowledge that causes } \\
\text { subject to violate a } \\
\text { prohibition }\end{array}$ & $\begin{array}{l}\text { Yearning to know that } \\
\text { which it is forbidden to } \\
\text { know }\end{array}$ \\
$\begin{array}{l}\text { Knowledge as disloyalty } \\
\text { to the rabbinic figure }\end{array}$ & $\begin{array}{l}\text { Knowledge as disloyalty } \\
\text { to parents }\end{array}$ & \\
$\begin{array}{l}\text { Knowledge as disloyalty to } \\
\text { parents }\end{array}$ & & \\
\hline
\end{tabular}

An ultra-orthodox Jewish way of life demands behavior according to an unequivocal ruling. Most areas of life preclude independent thought and decisions based on emotion and personal desires. These conflicts, between knowledge and tradition, are a micro-pattern of debate over two approaches - psychoanalysis and Judaism. In ultra-orthodox Judaism no question is raised without an answer. Within the therapeutic process, however, additional truths are revealed. The therapeutic spaces create new ways of looking; therapy leads to situations of ambiguity. Subjects who are used to receiving and obeying clear instructions, and are not comfortable with such ambiguity, will consciously and unconsciously do everything they can to reach clear guidelines.

In our psychotherapeutic processes, the subjects learned to open independent channels of thought and to see additional truths. This process of exposure to 
"knowledge" appears in the records of the treatment. In the first stages of therapy, when the subjects encountered an opinion different to that of orthodox Judaism, one of two reactions was observed: either objection and protest, or disregard and a return to existing patterns. The subjects found themselves facing two truths simultaneously, and deliberating how to deal with the practical part. In orthodox Jewish life every effort is made to avoid states of doubt and uncertainty. Consequently these states arouse disquiet and a desire to return to the familiar homeostasis.

As the subjects progressed in their therapy, their ability to live simultaneously "in two worlds" increased. There was an inner dialectic, and thus coping with the conflicts became more bearable. However, no clear acceptance of this dualism was apparent. The integration was generated gradually, creating a type of inner dialogue. The ability to think in a more independent manner and to dare to discuss these matters in the therapeutic framework emerged slowly. Religion and knowledge still remained two different voices.

Category 3: Drives and impulses

Sub-categories mapped from super-category 3 - drives and impulses - are presented below in Table 4.

Table 4: Categories for drives and impulses

\begin{tabular}{lll}
\hline Beginning stage of therapy & Middle stage of therapy & $\begin{array}{l}\text { Advanced stage of } \\
\text { therapy }\end{array}$ \\
\hline Drive to be feminine & Sexual drive not realizable & $\begin{array}{l}\text { Expressing forbidden } \\
\text { wishes }\end{array}$ \\
$\begin{array}{l}\text { Drive for personal expression } \\
\text { Sexual drive not realizable }\end{array}$ & $\begin{array}{l}\text { Ambiguity and curiosity } \\
\text { regarding sex }\end{array}$ & \\
Ambiguity and curiosity & & \\
regarding sex & & \\
\hline
\end{tabular}

Jewish religious law demands that people conquer and control their drives and impulses. The law does not deny them; on the contrary, they are recognized and permitted under certain circumstances, but they may only be expressed in a guided or controlled way. Anger, for example, is recognized as essential, but people are warned against allowing their anger to cause harm and are expected to control 
their anger at all times. Ultra-orthodox religious education in general educates to restraint in all spheres of life. In addition, the orthodox Jewish approach restricts every liberal creative impulse; people are required to control their impulses and to re-direct them according to what is permitted by religious law. In the ultra-orthodox religious community, every contact with the other sex is for marriage purposes only. Sexual relations are forbidden prior to marriage, and boys and girls are strictly separated in all educational frameworks from a very young age. There is no contact between males and females till marriage, and even then weddings are arranged. Masturbation is prohibited for males.

The subjects made use of the therapeutic framework in order to clarify issues in the realm of drives and impulses, femininity and sensuality in general. The content of the discussions varied from a naïve encounter with the unknown and the unfamiliar to intentional rebellious behavior. The pattern throughout was one of examining and clarifying the norms while becoming more aware of the differences. In addition, there was repeated questioning of whether something is prohibited or permitted. For these purposes, therapy became a place which allowed open conversation and attempts to understand the complexity of combining one's personal needs with Jewish orthodox life.

Two major aspects were considered: the orthodox community versus the outside world, and the intra-community observance - I versus my environment. These two variables indicate the feeling of difference. The internal struggle is over the need to belong by maintaining observance of the religious laws, in contrast to the need for personal fulfillment and attention to individual needs.

In our study, the feeling of difference was accompanied by harsh feelings of anger, frustration, jealousy and yearning. In the latitudinal observations, differences in the subjects' personalities could be noticed, since each of them was at their own individual therapeutic and personal level of development. Subjects faced issues ranging from questions of conscience, stemming from the super ego's response to the impulses, to the inability to cope with the conflict. This inability, in turn, arose because the subject was incapable of taking responsibility for his or her own needs, and transferred the responsibility onto the therapist in the process of projective identification.

We found that the younger subjects set their hearts' desires above religious law. This brought contentment that was connected to the non-observance of the commandments - objecting to and transgressing the laws, while sharing the secret with the therapist, and making sure that their parents and their surroundings would 
not find out. Similarly, there were expressions of rebellion, lack of agreement, and lack of commitment to the requirements to conform to the religious law and the environment. There was also an attempt to bend the framework towards personal needs, expressed in phrases such as "Me first", "Can't act according to the religious law", "Doesn't suit me" (subject no. 4). Such statements and rebellious expressions from the younger subjects can also be seen as characteristic of adolescence. Furthermore, questions arose regarding the presence of the super-ego. Half of the subjects appeared to use the mechanism of repression and ignoring or disregarding laws and customs, and the internalizations of the super ego.

Changes were observed amongst all the subjects at advanced stages of therapy. The framework, the intimacy and the space that opened up enabled them to talk about feelings, fantasies and the fulfillment of these fantasies. Containment and the processing of the conflicts (Bion, 1963), resulted in a greater sense of calm and a lowering of resistance. Hence, the therapeutic settings helped to realize the ability to verbalize issues, while providing an accepting rather than a critical framework. All these features enabled the subjects to find ways of coping with the complex encounters throughout the therapy.

Category 4: The therapist as an authority

Sub-categories mapped from super-category 4 - the therapist as an authority - are presented below in Table 5.

Table 5: Categories for the therapist as an authority

\begin{tabular}{lll}
\hline $\begin{array}{l}\text { Beginning stage of } \\
\text { therapy }\end{array}$ & Middle stage of therapy & $\begin{array}{l}\text { Advanced stage of } \\
\text { therapy }\end{array}$ \\
\hline Permission to be in therapy & $\begin{array}{l}\text { Questioning existing } \\
\text { authority }\end{array}$ & Who actually can help? \\
$\begin{array}{l}\text { Difficulty accepting } \\
\text { therapist as help }\end{array}$ & $\begin{array}{l}\text { Confusion between } \\
\text { authorities }\end{array}$ & \\
$\begin{array}{l}\text { Positive emotion causes } \\
\text { disquiet }\end{array}$ & \\
$\begin{array}{l}\text { Therapeutic connection } \\
\text { perceived as threatening }\end{array}$ & \\
\hline
\end{tabular}


The question of authority in therapy was always present. Figures familiar to the subject such as the rabbi, educator or parental figure were projected onto the therapist during the sessions. Confusion was created in the value and place of the therapeutic figure in the familiar hierarchy. The therapist was not a parent or a rabbi. So how should one relate to her? What should one say to her? To what extent should one believe in or rely on her? There was some confusion over the issue of "otherness". The fact that the therapist belongs to the same community created uncertainty and confusion. For if you are ultra-orthodox why are you different? If you are different, you are not really ultra-orthodox. And if not, who are you for me? The process of transference makes the parallel and the comparison between the therapist and the parent very complex. The narrative notes that in addition to the existing confusion about authority, there is also the presence of God - a given at all times for orthodox Jews. Next in the hierarchy is the rabbi, whose opinion is binding, followed by the community and its special norms, and then the parents. The attitudes towards the figure of the therapist range from glorification to negation, from idealization to devaluation. Spero (1996) states that such figures, God and the rabbinic authority, are projected in the transference process onto the religiously observant therapist; he/she must realize this and cope with this projection. In Spero's opinion, the unconscious and unspoken demand is for the therapist to be a rabbi, arbiter and guide. The narratives indicate that there is confusion among the parental figures and the question of "Who holds the authority" was repeated constantly.

On the longitudinal axis, it seems that this question was prominent at the start of the therapy, when testing, deliberation and confusion, often followed by resistance, were still part of the process. At a later stage, diverse transference feelings such as identification with the therapist, jealousy, competition, envy of the therapist's professional status and anxiety about the trust placed in her added to the existing confusion regarding the therapist's authority.

On the latitudinal axis, the issue of authority was affected by components such as age, family status, personality type and the place in therapy. On this latitudinal cross section, differences between the various subjects were also observed regarding their ability and readiness to accept the therapeutic authority. The adults tended, at the start of therapy, to trust the therapist. With its progress, transference and identification, the feelings of jealousy and competition became more prominent. As the process advanced, subjects began to question the therapist's authority more. Adolescents, on the other hand, protested against the parents and every other authority, but tended to accept the therapist as an authority and as a partner to their situation and secrets. 
Category 5: Guilt as an emotion

Sub-categories mapped from super-category 5 - guilt as emotion - are presented below in Table 6.

Table 6: Categories for guilt as emotion

\begin{tabular}{lll}
\hline $\begin{array}{l}\text { Beginning stage of } \\
\text { therapy }\end{array}$ & Middle stage of therapy & $\begin{array}{l}\text { Advanced stage of } \\
\text { therapy }\end{array}$ \\
\hline $\begin{array}{l}\text { Guilt for being in therapy } \\
\text { Consciousness and insight } \\
\text { Therapy arouses guilt }\end{array}$ & $\begin{array}{l}\text { Fantasies } \\
\text { and heart's desires } \\
\text { about disloyalty }\end{array}$ & $\begin{array}{l}\text { Softening in the personality } \\
\text { arouses guilt }\end{array}$ \\
$\begin{array}{l}\text { Guilt about freedom in } \\
\text { speech }\end{array}$ & \\
\hline
\end{tabular}

Admitting an error or a sin and regretting it is one of the signs of repentance that may lead a person to renew the covenant with his Creator. In "The Laws of Repentance" (ch. 1) by Maimonides (b. 1138, d. 1204) we read: "If a person has infringed one of these, whether deliberately or unintentionally, when he repents he is required to confess this to the Holy One Blessed be He". A person who has undergone a process of repentance recognizes his sin, admits it and commits himself not to repeat such a sin in the future. According to the Talmud, such a person will be held in high regard due to the magnitude of the process of repentance (Tractate Brachot, p. 34).

The arousal of the feeling of guilt is a sign of responsibility and of recognizing one's errors. According to Melanie Klein, guilt arises because of aggressive drives. In addition, the reparation of what has been damaged in fantasy, and the wish for such reparation, arise from a feeling of concern and responsibility towards those one loves (Klein, 1937). The arousal of the feeling of guilt is also a type of self-punishment, a type of atonement for what is felt to be a sin (Freud, 1907). This feeling is very commonly seen in the ultra-orthodox psychotherapy clinic. It may be expressed as a sense of anxiety, together with the desire for absolution and change. Guilt is perceived as a lever for repentance and is thus a type of logical solution to conflict.

Based on our findings, we can assume that therapy may lead to a sense of transgression, but it may also lead to knowledge, insight and understanding. There is a change in the perception of the world, in thought and in observation. In the therapeutic process the subject has received "permission" to contemplate and 
question. All this, however, exists only in the inner world, and not at the concrete level. Questions and contemplation, insights, thoughts and fantasies (even when not carried out), are regarded as a sign of spiritual decline and create a feeling of guilt.

\section{Summary of the semi-quantitative findings}

A summary of findings is presented in Table 7 and graphically, for each participant, in Figures 2-5.

Table 7: The research findings

\begin{tabular}{lllll}
\hline Objective & Patient & $\begin{array}{l}\text { Beginning } \\
\text { therapy }\end{array}$ & $\begin{array}{l}\text { Middle } \\
\text { therapy }\end{array}$ & $\begin{array}{l}\text { Advanced } \\
\text { therapy }\end{array}$ \\
\hline Treatment & 1. Chavazelet & - & + & + \\
compliance & 2. Yael & -- & -+ & ++ \\
& 3. Assaf & -+ & -+ & + \\
& 4. Keren & -+ & + & ++ \\
Attitude to and & 1. Chavazelet & ++ & + & +- \\
impact of & 2. Yael & ++ & -+ & - \\
religious values & 3. Assaf & - & - & -- \\
and laws & 4. Keren & -+ & - & -- \\
\multirow{2}{*}{ Overall } & 1. Chavazelet & + & + & ++ \\
progress & 2. Yael & -+ & + & ++ \\
& 3. Assaf & - & -+ & + \\
& 4. Keren & -+ & + & ++
\end{tabular}

++ Marked improvement or strengthening; + Slight to moderate improvement or strengthening; +No apparent change; - Slight religious compliance; - - Marked moderate religious compliance

Figure 2: Chavatzelet. The response scale used: $2=++, 1=+, 0=+-,-1=-,-2=-$ -

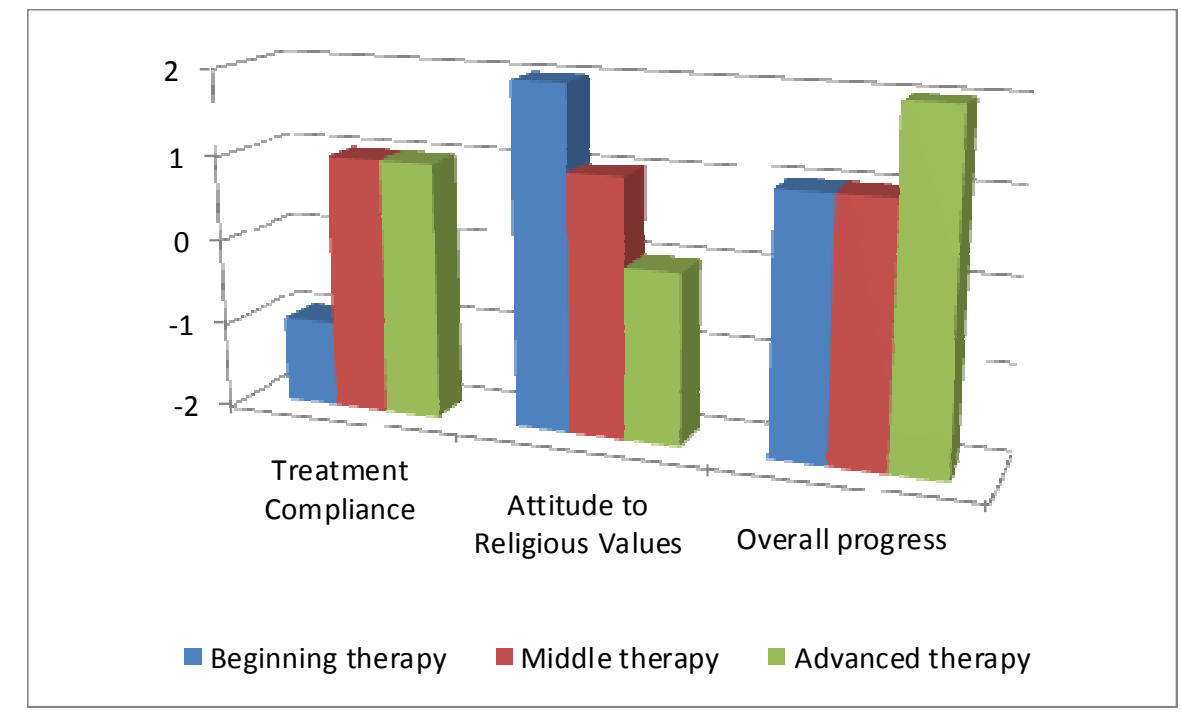


Figure 3: Yael. See legend to figure 2

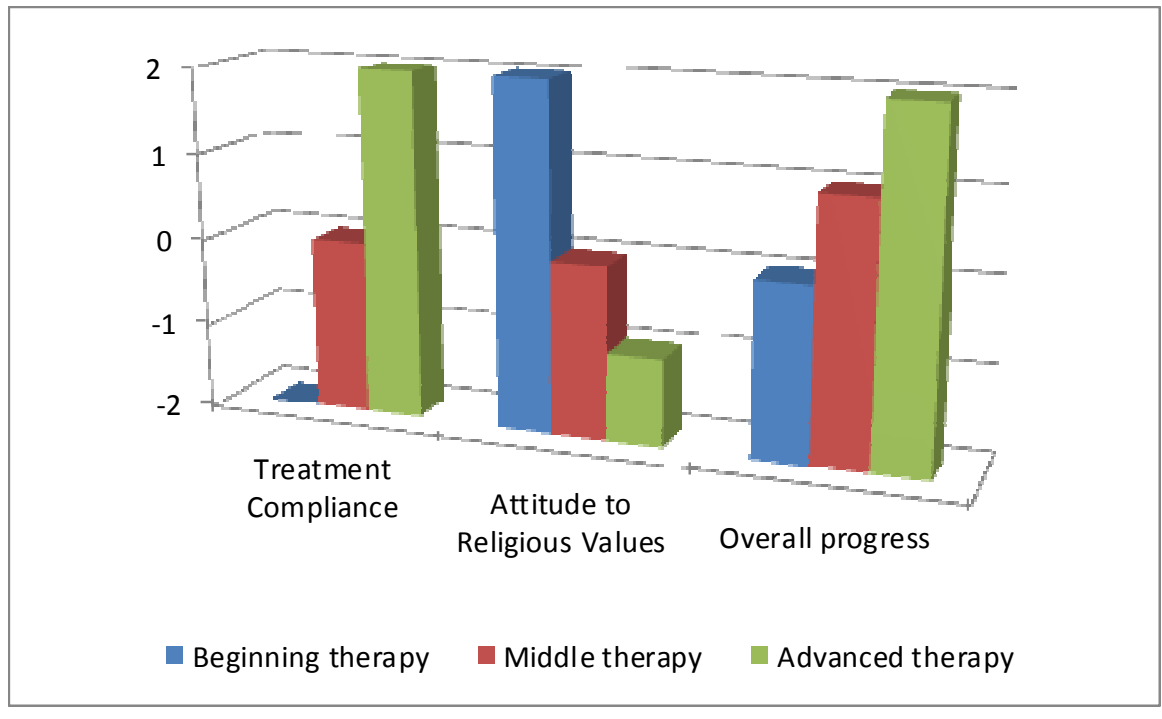

Figure 4: Assaf. See legend to figure 2

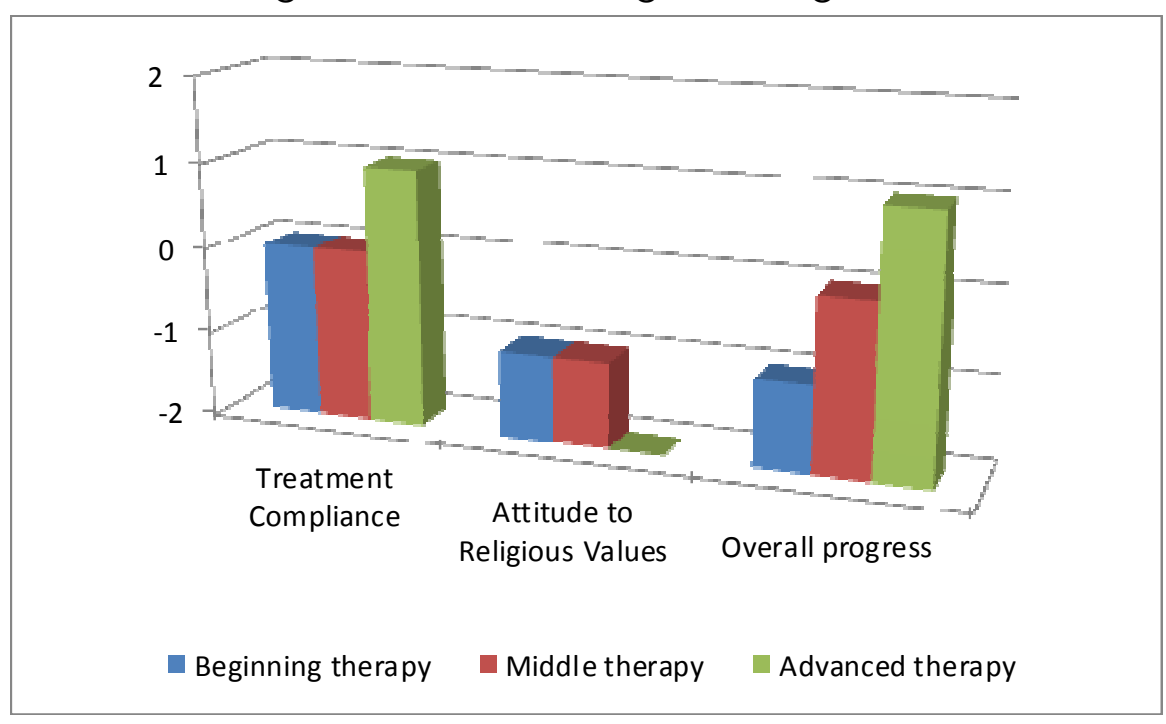

Figure 5: Keren. See legend to figure 2

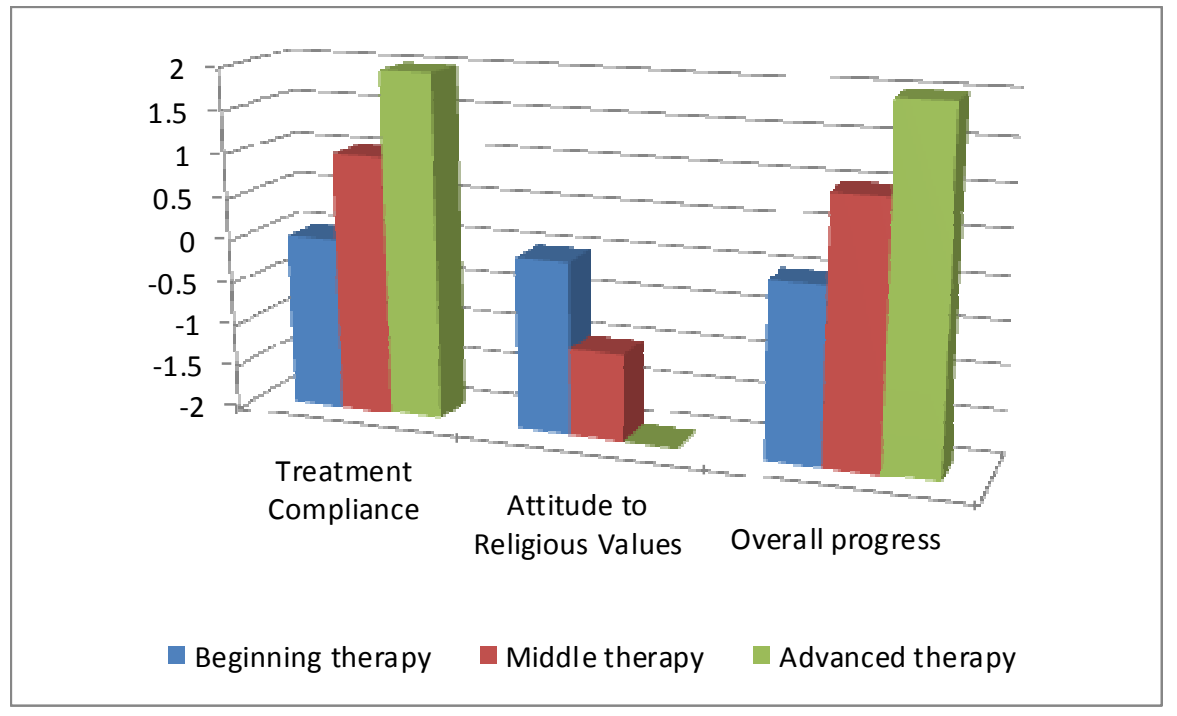


The findings presented in Table 7 and figures 2-5, shown here in a semi-quantitative manner, indicate a correlation between the process and progress in therapy and a move towards a decline in religious perception and adherence. This observation is in line with the common assertion that opening of the spaces for thought and observation leads to a softening of the super ego, which in turn is an accelerating factor in the decline in religious observance.

It might be concluded, from the sample of this study, that similar findings could occur in the exposure to openness within the therapeutic process in cases where patients belong to a closed community or group and follow a religion that requires close adherence to rules and restrictions. One may well assume that openness, knowledge, understanding, insight and expanding the inner world may lead to a decline in spiritual faith.

\section{Discussion}

An endless journey between space and boundaries, between the possible and the impossible, and between the prohibited and the permitted occurs in human development. There is a fundamental conflict between Judaism and psychoanalysis: Judaism requires maintaining the traditions and religious laws, while psychoanalysis regards a person as an entity entitled to freedom of thought and action. In Orthodox Judaism, questions or doubts are resolved by the decision of a rabbi or by referring to earlier decisions made by scholars of Halacha. Life habits are based on boundaries. The possibilities are limited to the domain of what is permitted according to religious law and accepted according to tradition and norms. Thought is limited to the familiar world of concepts. The religiously observant person has a God who is central to his or her being. In the words of King David, "I have set the LORD always before me" (Psalms 16, p. 8).

Psychotherapy does not normally regard God as a central element in therapy. An ultra-orthodox subject, however, always enters therapy together with Him and He is a continual presence there. Several authors have addressed this issue. Kristeva (2004) compares the transference to the therapist to the attitude to God. She sees the subject's relation to the therapist as to an "omnipotent parent". In her view, love of the object becomes the love of God, and this love is transferred to the therapist. Caspi (2002) is very critical of the classic psychoanalytic orientation, in which all issues of sexuality, aggression, selfishness, and childishness are gladly accepted, but there is no room to speak about God or to regard Him as a presence in the therapy. It should be noted, however, that there are indeed additional presences in the therapy room besides the subject, the therapist and the transference projected onto 
him. Ogden (1989) developed the concept "the analytical third" meaning an entity, an essence created in the encounter between two people. This concept will help to understand the presence of the "third" within the therapeutic session where both therapist and subject are religiously observant. The Halacha, rabbinical authority and the norms of the community are all present as concrete value entities of considerable impact. Levinas (1982, p. 14) uses the term "the third" ("le tiers") to describe this situation. "When there are two there are three". He explains that the address of the one to the "other" is the third. One type of presence addressed is God. Levinas (2002) explains that where there is morality in "the meeting with the friend", there the fear of God will also be present. In his view, morality and religion are interwoven, and morality is the essence of religion. The 'fear of man' and moral behavior towards others - these elements constitute the fear of God. The fear of God begins with the 'fear' or respect for the other, which is in itself evidence of the presence of God. Levinas' views are ethical rather than religious. He believes that every individual human being is for the other and takes responsibility for the other.

When considering the concept of "the third" in the thinking of Levinas and Ogden, we need to add the concept of the "first" and to differentiate between the "third" and the "first". For ultra-orthodox Jews, divine authority is supreme and binding at all times, preempting any interpersonal relations and certainly also a therapeutic session. The authority of God takes priority over any human and interpersonal contact and should be regarded as "the first". In addition to this divine "first", always present according to the Jewish perception, there is also the "third". These are the voices of the Halacha, of rabbinical authority and also the authority of one's parents and teachers - human authorities in the religious hierarchy. All these "presences" burden the therapeutic process and restrict the space and freedom. The constant presence of the "third", which is more concrete, is also the constant and significant presence of the super ego and of internalization. From the above, we can understand the uniqueness and the special sensitivities of psychoanalytical therapy in the ultra-orthodox Jewish community. In these therapies, there is a permanent divine presence in addition to the two people who are in the room. Additional presences are found in every therapeutic session, both in the subject's inner world and in that of the therapist.

The research findings show that:

1. The subjects deal with the conflicts through fixation (remaining in the conflict), compromise or mediation. As the therapy progresses, there is an attempt at and a movement towards integration.

2. There are two poles of internalization of the super ego, ranging from rigidity to disregard for the laws of religious observance. Younger patients tend to 
rebellion and disregard and to the destruction of the norms in order to develop an identity. Adult subjects take responsibility and suffer from pangs of the super ego. Softening is observed as the therapeutic process progresses.

3. Emotions and deeds of a contradictory character do indeed occur. Clearly, psychotherapy encourages and enables their manifestation. It is reasonable to assume that thoughts, fantasies and attempts at fulfillment existed previously in the person's inner world. The therapeutic framework enables abreaction, processing and insights.

It is worth noting that thoughts, desires and ambitions are aroused in some subjects as a form of disregard or disobedience in relation to the Halacha and as a decline in spirituality, which does not have to be real but a subjective feeling. A reduction in the observance of the religious laws may be noted, with the psychotherapy functioning as a catalyst due to its enabling effects. There is no proof that it was a unique factor however.

The limitations of an ultra-orthodox way of life obviously create boundaries that limit the therapeutic space, the freedom of thought, the closeness and the discussion that are at the heart of psychotherapy. Limiting the space only to permitted domains excludes the areas of "no man's land" - those areas that cannot be opened and discussed. Instead of freedom and a broad spectrum of recollection, imagination, speech, thought and permission to be, the space of both the subject and the therapist becomes narrow and rigid. This is certainly true of the potential space between them, the place where creativity and development are feasible (Winnicott, 1971). Furthermore, the diminution of space and the reservations about touching the possibilities and opening new worlds reduce the dimension of depth in thought and insight, replacing it with technical and practical involvement that gives a feeling of flattening or of two dimensions (Melzer, 1978).

Victor Frankel (1985) writes that in the psychoanalytic approach, the unconscious is viewed as motivated solely by drives and impulses. In Frankel's view, however, each person has a 'spiritual unconscious' which includes drives and impulses as well as spiritual elements. Rosenberg (2004: 230) believes that within the awareness of human freedom, there is inner evidence of the wars and the conflicts that occur within us. There is an awareness of the existence of dilemmas, hesitations and uncertainties and also of a tragic sense of oppression which is linked to the decisions that we make at critical junctures in our lives. In Jewish tradition this psychological situation is described as "the battle of the impulses" (free translation of the Hebrew term "milhemet ha-yetzer"). 
There is no exact scientific way to examine whether such intra-emotional processes would occur anyway. A central variable here appears to be the power of the super ego. When the super ego does not exist or is pale and weak, a decline in religion and religious observance is anticipated. In our study the practical act of abandoning religion following psychotherapeutic treatment is not observed. A clear finding is that the therapy simultaneously contains the emotional struggles and "causes" them, thereby accelerating the complex processes which the subject experiences. Rotenberg (2001) mentions doubt vs. certainty, i.e., two directions simultaneously, enforcement and desire. An example of this is a child who wishes to study. If he is forced to cease studying the natural desire will come of itself. This is the paradoxical theory and method of treatment developed by Erikson (1996) and Watzlawick et al. (1974), whose concept is that forcing a strict, fundamental solution leads to spontaneous action. Here, too, when we ask whether psychotherapy causes a decline in religious observance, the way in which the question is posed is significant. Such a decline may be a reaction to the feeling of decisiveness, but from the paradoxical perspective, affording freedom to think, do and choose may actually prevent or modify the decline.

This material shows that a decline in religious observance ("spiritual decline") during the psychotherapeutic process is a topic that can be debated endlessly. Spiritual decline is a subjective concept. Doubts, questions, deliberations, thoughts and insights - all these may be contained by the personality and be experienced as enriching, pluralistic and enabling the holding of different viewpoints simultaneously. However, these same processes may also be experienced as subjective feelings of uncertainty, restlessness or a disturbance in homeostasis and consequently as a decline in spirituality. The concept of "spiritual decline" may be interpreted differently by each subject and depends on his or her personal feelings.

As a result of environmental and community pressure and due to personal conflicts that arise in the subjects, there is a need for emotional balance, which the therapy tries to meet. Continuing in therapy provides an anchor and a sense of stability. Eshel (2003) writes that for a subject to be able to project - to rid himself or herself of the unbearable parts, to rest and be processed - there should be someone who is ready to devote himself/herself to starting this process - a process that can occur only in the connection with and through the soul of the other.

It would be interesting to continue studying what happens to the subject's self in the therapeutic process. This study does not explore issues such as the subject's jealousy of the therapist when both are members of the same reference group; or the transference process and its implications for the therapist's place and for the 
patient's life, when both therapist and subject belong to the same reference group; and other facets of this topic.

This research has been, and continues to be, a journey of sharing and visiting the personal clinical space of the researcher, within the context of a closed orthodox Jewish community. It portrays the meeting of ideas which takes place in the therapy room between an orthodox therapist and an orthodox patient, in a situation where the patient is exposed to knowledge and conflicts and the therapist is a witness to a complex internal struggle while also being a partner to this struggle from a human, containing, professional and religious standpoint.

Note: This article was written in the framework of the PhD thesis of the first author, at the UBB Cluj, Romania, under mentoring by the late Prof. Horia Pitariu. Since the untimely passing of Prof. Pitariu, the research presented here is being completed under the supervision of Professor 1. Dafinoiu at the Alexandru loan Coza University, lasi. This paper describes a new research approach which Prof. Pitariu worked on during his lifetime. This article is dedicated to his memory.

\section{References}

Adahan, M. (1997). E.M.T. Jerusalem: Feldheim. [Hebrew]

Adahan, M. (2002). Awareness. Jerusalem: Feldheim. [Hebrew]

Adahan, M. (2005). To understand, to respect, to love. Jerusalem: Feldheim. [Hebrew]

Amsel, A. (1969). Judaism and psychology. New York: Feldheim.

Arnovitz, Y. (2003). Psychoanalysis and religion in a renewed encounter. In: Y. Hatab (Ed), Psychoanalysis in practice and principle. Tel Aviv: Diyunon. [Hebrew]

Bilu, Y., \& Witztum, E. (1994) Culturally sensitive therapy with ultra-orthodox patients: The strategic employment of religious idioms of distress. Israel Journal of Psychiatry, 31:170182.

Bion, W. (1959). Attacks on linking. International Journal of Psychoanalysis, 40, 5-6, 308.

Bion, W. (1962). Learning from experience. London: William Heineman Medical Books.

Bion, W. (1963) Elements of Psychoanalysis. London: Karnac Books. 
Bion, W. (1965). Transformations. London: Karnac Books.

Bion, W. (1967). Second thoughts. London: William Heineman Medical Books.

Bion, W. (1970). Attention and interpretation. London: Karnac Books.

Bion, W. (1992). Cogitations. London: Karnac Books

Buber, M. (1962). The human face: Studies in psychological anthropology. Jerusalem: Bialik. [Hebrew]

Buber, M. (1976). The hidden light. Tel Aviv : Schocken. [Hebrew]

Carter, K. (1993). The place of story in study of teaching and teacher education. Educational Researcher, 25(3):24-30.

Case, P.W. (1997) Potential sources of counter transference among religious therapists, Counseling and Values, 41 (2):97-106.

Caspi, Y. (2002). To demand God. Tel Aviv: Hemed. [Hebrew]

Cohen, P. (1994) An interesting contradiction: A study of religiously committed, psychoanalytically oriented clinicians, Journal of Psychology and Theology, 22(4),pp.304318.

Coltart, N. (1992). The superego, anxiety and guilt. Free Associations, 38, 243-259.

Creswell, J.W. (1998). Qualitative Inquiry and Research Design Choosing Among Five Traditions. Thousand Oaks, CA: Sage Publications.

Erickson, M.(1996). My voice will go with you. S.Rosen(Ed.),Nord Publications. [Hebrew]

Erikson, E. (1968). Identity, youth and crisis. Tel Aviv: Sifriyat Hapoalim. [Hebrew]

Erlanger, S. (1988). Orthodox Jewish psychotherapists face conflicts, New York Times, April 25, pg. B2.

Eshel, O. (2003). Thoughts about Bion's concept of Jewish Halacha. In, Y. Hatab. Psychoanalysis -theory and practice. Tel Aviv: Diyonon. [Hebrew] 
Feinstein, M. (1973). Letters from Moshe. New York and Bnei Brak: Private publishing. [Hebrew]

Frenkel, V. (1985). The unknown God. Tel Aviv: Dvir. [Hebrew]

Freud, S. (1907). Obsessive acts and religious practice. In, S.E. vol. IX, 116-130, London: Hogarth.

Freud, S. (1923). The ego and the id. In, S. E. Vol. XIX: 3-108. London: Hogarth.

Giglio, J.(1993). The impact of patients' and therapists' religious values on psychotherapy. Hospital and community Psychiatry, 44 (8), pp. 768-771.

Ginsburgh, Y. (2004a). Turning the darkness into light. Kfar Chabad: Gal Eyni. [Hebrew]

Ginsburgh, Y. (2004b) A healthy soul. Kfar Chabad: Gal Eyni. [Hebrew]

Geertz, C. (1990). Interpretation of culture. Jerusalem: Keter. [Hebrew]

Greenberg, D. \& Witztum, E. (2001). Sanity and sanctity. New Haven and London: Yale University Press.

Hoffman, S. (2007). Issues in psychology, psychotherapy and Judaism. University Press of America.

Houts, A.C. \& Graham, K. (1986) Can religion make you crazy? Impact of client and therapist values on clinical judgment. Journal of Consulting and clinical psychology, 54 (2), pp. 267-271.

Huberman, A.M., \& Miles, M.B. (1994). Data management and analysis methods. In, N.K Denzin \& Y.S. Lincoln (Eds) Handbook of qualitative research. Thousand Oaks, CA: Sage Publications.

Irvine, K.A. (2003) The sacred vs. the secular: Evangelical Christian psychologists' religious values and ethical practice, Doctoral Dissertation, The University of British Columbia.

Klein, M. (1937). Love, guilt and reparation; and other works. Tel Aviv: Tola'at (2002). [Hebrew].

Kristeva, J. (2004). In the beginning there was love. Tel Aviv: Ressling. [Hebrew]

Levinas, E. (1982). Ethics and the infinite. Jerusalem: Magness. (Reprinted 2002) [Hebrew] 
Levinas, E. (2007). Emanuel Levinas in Jerusalem: Philosophical interpretations and religious perspectives. J. Hansel (Ed.). Jerusalem: Magness. [Hebrew]

Maimonides (Ben Maimon, M.) Mishne Torah. Jerusalem: Rav Kook Institute. Pub. 1961) [Hebrew]

Marx, J.H. \& Spray, S. (1972) Psychotherapeutic "birds of a feather": Social class status and religio-cultural value homophily in the mental health field, Journal of Health and Social Behavior. 13(4), pp. 413-428.

Melzer, D. (1978). Dimensionality as a parameter of mental functioning: Its relation to narcissistic organization. In, D. Meltzer, J. Bremmer, S. Hoxster, D. Weddell, I. Wittenberg (Eds.) Explorations in Autism. New York: The Ronald Harris Educational Trust.

Novis Deutsch, N. (2010). Two world views meet: How Jewish religious psychotherapists in Israel deal with value conflicts between Judaism and dynamic psychology PhD. dissertation. Jerusalem: Hebrew University. [Hebrew]

Ogden, T. H. (1989). The primitive edge of experience. Tel Aviv: Am Oved. [Hebrew]

Rosenak, M. (2003). In need of investigation: Tradition, and moderna in modern Jewish education. Jerusalem: Magness. [Hebrew]

Rosenak, M. (2005). Theology of Jewish education - directions in the philosophy of Michael Rosenak. In: Y. Cohen (Ed), Who is the educating Jew. Jerusalem: Magness. [Hebrew]

Rosenberg, S. (2004). The search for meaning: Soul in Jewish philosophy. In: S. Arazi, M. Fachler \& B. Cahana (Eds), Life as a legend - issues in Jewish psychology. Tel Aviv: Miscal. [Hebrew]

Rosenheim, E. (2003). My soul desires you: Psychology meets Judaism. Tel Aviv: Yediot Aharonot. [Hebrew]

Rosenheim, E. (2004). Axioms of the sages on human psychology. S. Arazi, M. Fachler and B. Cahana (Eds). Life as a legend-issues in Jewish psychology. Tel Aviv: Miscal. [Hebrew]

Rosenheim, E. (2008). Psychology in Judaism. Tel Aviv: Modan. [Hebrew]

Rotenberg, M. (1990). Existence through reduction. Jerusalem: Bialik. [Hebrew] 
Rotenberg, M. (1994). Christianity and psychiatry. The theology behind the psychology. Tel Aviv: Ministry of Defense. [Hebrew]

Rotenberg, M. (1997). Psychology, Judaism and Hassidism. Tel Aviv: Ministry of Defense. [Hebrew]

Rotenberg, M. (2001). From sanctuary to legend. Fundamentalism, psychology and Judaism. Jerusalem: Schocken. [Hebrew]

Rotenberg, M. (2004). Jewish psychology, science or the psyche. In: S. Arazi, M. Fachler \& B. Cahana (Eds) Life as a legend - issues in Jewish psychology. Tel Aviv: Miscal. [Hebrew]

Rotenberg, M. (2005). Bereavement and legend. Not the deed but the legend counts. Tel Aviv: Miskal. [Hebrew\}

Sabar Ben Yehoshua, N. (2002). Quantitative research - a view to the future. In: A. Shai \& Y. Bar Shalom (Eds) Qualitative research in the study of education. Jerusalem: David Yellin College of Education. [Hebrew]

Sciarra, D. (1999) The role of the qualitative researcher. In: M.S. Kopele, \& L.A. Sucuki (Eds), Using Qualitative Methods in Psychology. London: Sage Publications.

Selman, R.L. (1980). The growth of interpersonal development and clinical analysis. London: Academic Press.

Sieve, C.B. (1999). Counter transference experiences in the analysis of religious material in psychoanalytic psychotherapy: an intersubject analysis. Doctoral Dissertation, Massachusetts School of Professional Psychology.

Shkedi, A. (2002). Worlds that collide and connect: Teachers' reactions to studies in education. In, A. Shai and Y. Bar Shalom (Eds.), Qualitative research in education. Jerusalem: David Yellin College of Education. [Hebrew]

Shkedi, A. (2003). Words that try to touch. A qualitative study, theory and practice. Tel Aviv: Ramot. [Hebrew].

Sheffler, G. (1989). Studies in psychotherapy. In, H. Dassberg, Y. Izikson and G. Sheffler (Eds). Short-term psychotherapy - background, techniques and application. Jerusalem: Magness. [Hebrew] 
Sheffler, G. (1994). Studies in dynamic psychotherapy. Did you exist or was it a dream. In, Sichot, vol. 8, 2. [Hebrew]

Spero, M.H. (1980). Judaism and psychology: Halachic. perspectives.Jerusalem: Ktav

Spero ,M.H. (1981) Counter transference in religious therapists of religious patients, American Journal of Psychotherapy, 35 (4), pp.565-575.

Spero, M.H. (1996). Psychotherapy of the religious patient. Rowman and Littlefield

Twerski, A.J. (1997). Getting up when you're down. Jerusalem: Shaar

Twerski, A.J. (1999). It's not as tough as you think: How to smooth out life's bumps. Mesora Publications.

Walker, R.V. (1993). The conduct of educational case studies. Ethics, theory and procedures. In: M. Hammersley (Ed) Controversies in classroom research. Buckingham: Open University Press.

Walker D. F, Gorsuch, R.L., \& Tan, S.Y. (2004). Therapists' integration of religion and spirituality in counseling: A meta analysis, Counseling and values. 49(1) pp. 69-80.

Watzlawick, P. Weakland J. and Fisch, R .(1974) Change, Principles of Problem Formation and Resolution. W. W. Norton Publications .

Weisbord, A. (1982) Impact of presession information regarding therapist counseling style and similarity of religious values on religious Jewish clients, Doctoral Dissertation, The American University.

Winnicott, D.V. (1971). Playing and reality. Tel Aviv: Am Oved. [Hebrew]

Yin, R.K. (1994). Case study research (2nd edition). Thousand Oaks: Sage.

The Book of Psalms

Babylonian Talmud - tractate Brachot 


\section{About the authors:}

Esther Hess is a psychotherapist, a lecturer at the Jerusalem College in Bayit Vegan and an instructor in the Child and Youth program at the Bar llan University. She herself belongs to the ultra-orthodox Jewish community in Israel, and is rather exceptional there in that most of its members do not normally acquire a university-level academic education. A graduate of the Program of Psychoanalytic Psychotherapy for Advanced Psychotherapists run by the Israel Psychoanalytic Institute, she maintains a private psychotherapy practice in Bnei Brak, Israel, a town with a large ultra-orthodox population. She researches the subject of therapy within this group, lectures in various frameworks and has published several articles on the subject.

Address for correspondence: Esther Hess, 14 Elisha St. Bnei Brak, Israel 515235

Email: ehess@netvision.net.il

Prof. Horia Pitariu was a lecturer and head of the Department of Psychology, UBB University, Cluj, Romania for many years. His areas of interest included Industrial and Organizational Psychology, Human Resources Assessment and Management, Experimental Psychology and Statistical Methods in Psychology. Romanian and international psychology suffered a heavy loss with his untimely demise. 